\title{
1100 \\ Changes in Births to New York City Residents Occurring Outside New York City, by Race and Hispanic Origin of the Mother: 2018-2019 and 2019-2020
}

\author{
Elizabeth C.W. Gregory, M.P.H., Michelle J.K. Osterman, M.H.S., and Claudia P. Valenzuela, M.P.H.
}

\section{Abstract}

Objectives - New York City was an early epicenter of the COVID-19 outbreak in the United States, with cases peaking in early April for JanuaryDecember 2020. This report describes changes between 2019 and 2020 in the percentage of New York City residents giving birth outside of New York City by race and Hispanic origin of the mother, and makes comparisons with changes occurring between 2018 and 2019.

Methods-Data are based on 2018 and 2019 final and 2020 provisional birth certificate data for births to residents of New York City. Changes in the percentage of out-of-city births occurring from 2018 to 2019 and from 2019 to 2020 are computed for each month and compared.

Results-From 2019 to 2020, the percentage of births to New York City residents occurring outside of the City increased for all months from March through November, ranging from a $15 \%$ increase for September to a $70 \%$ increase for April. Out-of-city births peaked in April (10.2\%) and May (10.3\%) at more than one and one-half times the 2019 levels (6.0\% and $6.2 \%$, respectively). Among non-Hispanic white women, the percentage of out-of-city births was nearly two and one-half times higher in 2020 than in 2019 in April (15.6\% versus $6.6 \%$ ) and May (15.8\% versus $6.5 \%$ ). Increases were less pronounced for births to non-Hispanic black and Hispanic residents; the percentage of out-of-city births for each group increased in only two months in 2020 . In contrast, few statistically significant changes were observed between 2018 and 2019 in the percentage of out-of-city births for New York City residents overall, or residents of the three largest race and Hispanicorigin groups.

Keywords: out-of-city births • provisional data $\cdot$ National Vital Statistics System

\section{Introduction}

New York City (NYC or City) was an early epicenter of the COVID-19 outbreak in the United States, with the introduction of COVID-19 into NYC likely occurring during early to midFebruary 2020 (1). During JanuaryDecember 2020, the 7-day average of confirmed and probable COVID-19 cases peaked in early April, declined and plateaued at a low from June to October, and then began increasing again (2). Between March 1 and May 1 , approximately $5 \%$ of NYC residents relocated from the City, with a higher percentage of residents leaving from the wealthiest neighborhoods compared with the rest of NYC (3). The residents from wealthier neighborhoods were more likely to be white, have higher incomes, have a college degree, and have the ability to work from home than residents of the City as a whole (3). Included in those leaving NYC were pregnant women who gave birth elsewhere. Reasons that pregnant women left NYC included concerns about the increased spread of COVID-19 in the City, the accompanying strain placed on the health care system, and a brief ban on the presence of support persons during labor and delivery in some hospital systems (4-6). This report presents the percentages of $\mathrm{NYC}$ residents giving birth outside of NYC by race and Hispanic origin of the mother by month for 2020 and compares these figures with percentages for the same month in 2019. Comparisons are also made with changes occurring from 2018 to 2019.

\section{Methods}

The birth certificate data shown in this report are collected via the National Vital Statistics System. For 2020 births to NYC residents, findings are based on provisional birth certificate data, representing $99.87 \%$ of births occurring in the United States. Comparisons are made with final 2018 and 2019 births. Detailed information on reporting completeness and criteria may be found elsewhere (7-9).

Out-of-city births are defined as those that occurred to women who resided in NYC but gave birth in a different jurisdiction. Birth certificates are filed in the jurisdiction where the birth occurred, but include information collected from the mother on her place of residence (10). Births are typically shown by state of residence in National Center for Health Statistics reports; state of residence was missing for $0.01 \%$ of births occurring in the United States in 2020. Births were included in the analysis if a woman reported that her place of residence was NYC, regardless of where the birth took place. 
Hispanic origin and race are reported separately on the birth certificate. Data shown by Hispanic origin include all persons of Hispanic origin of any race. Data for non-Hispanic persons are shown separately for each single-race group. Data by race are based on the revised standards issued by the Office of Management and Budget in 1997 (11). The race and Hispanic-origin groups shown are non-Hispanic, single-race white; non-Hispanic, single-race black; and Hispanic. For brevity, text references to non-Hispanic white or non-Hispanic black women omit the term "singlerace."

Changes and differences presented in this report are statistically significant at the 0.05 level based on a two-tailed $z$ test, unless noted otherwise. For information and discussion on computing percentages and on the reliability of provisional natality data, see "Births: Provisional Data for 2016" (12).
Results

\section{Changes in place of occurrence of NYC resident births between 2018 and 2019}

Key findings, illustrated in the Table and Figure 1, include:

- The percentage of all NYC residents and of the three largest race and Hispanic-origin groups giving birth outside of the City was essentially unchanged for most months in 2019 compared with the same months in 2018. The only significant changes in the percentage of out-of-city births were a $20 \%$ increase in February 2019 for all residents (5.1\% to $6.1 \%$ ) and for non-Hispanic black (51\%, from $4.1 \%$ to $6.2 \%$ ) and Hispanic (33\%, from $4.5 \%$ to $6.0 \%$ ) residents, a 42\% increase in December 2019 for non-Hispanic black residents $(5.3 \%$ to $7.5 \%$ ), and a $19 \%$ decline in April
2019 for non-Hispanic white residents $(8.1 \%$ to $6.6 \%)$.

\section{Changes in place of occurrence of NYC resident births between 2019 and 2020}

Key findings, illustrated in the Table and Figures 1 and 2, include:

- The percentage of all NYC residents giving birth outside of the City was essentially unchanged between 2019 and 2020 in January and February but rose from March to November, with levels peaking in April and May. The change in the percentage of out-of-city births for December was not significant. In March, out-ofcity births increased by $33 \%(5.8 \%$ to $7.7 \%$ ), in April by $70 \%$ (6.0\% to $10.2 \%)$, and in May by $66 \%$ (6.2\% to $10.3 \%$ ). Out-of-city births continued to rise for June through November with increases ranging from $15 \%$ to 33\% (Table and Figure 1).

Table. Births to New York City residents that occurred outside of New York City, by month and race and Hispanic origin of mother: Final 2018 and 2019 and provisional 2020 data

\begin{tabular}{|c|c|c|c|c|c|c|c|c|}
\hline \multirow[b]{2}{*}{ Race and Hispanic origin and month } & \multicolumn{3}{|c|}{ Number } & \multicolumn{3}{|c|}{ Percent } & \multicolumn{2}{|c|}{ Percent change } \\
\hline & $2018^{1}$ & $2019^{1}$ & $2020^{2}$ & $2018^{1}$ & $2019^{1}$ & $2020^{2}$ & 2018-2019 & 2019-2020 \\
\hline \multicolumn{9}{|l|}{ All race and Hispanic origins ${ }^{3}$} \\
\hline January & 568 & 507 & 502 & 6.0 & 5.7 & 5.8 & -5 & 2 \\
\hline February & 420 & 475 & 502 & 5.1 & 6.1 & 6.3 & $\dagger 20$ & 3 \\
\hline March & 515 & 496 & 651 & 5.7 & 5.8 & 7.7 & 2 & †33 \\
\hline April & 547 & 506 & 824 & 6.4 & 6.0 & 10.2 & -6 & $\dagger 70$ \\
\hline May & 576 & 545 & 839 & 6.2 & 6.2 & 10.3 & 0 & $\dagger 66$ \\
\hline June & 596 & 586 & 674 & 6.5 & 6.7 & 8.4 & 3 & $\dagger 25$ \\
\hline July & 604 & 616 & 668 & 6.4 & 6.7 & 7.9 & 5 & $\dagger 18$ \\
\hline August & 588 & 580 & 670 & 6.1 & 6.1 & 8.1 & 0 & †33 \\
\hline September & 554 & 579 & 611 & 6.2 & 6.5 & 7.5 & 5 & $\dagger 15$ \\
\hline October & 494 & 547 & 606 & 5.4 & 6.0 & 7.5 & 11 & $\dagger 25$ \\
\hline November & 512 & 473 & 533 & 5.7 & 5.5 & 7.3 & -4 & †33 \\
\hline December & 530 & 566 & 468 & 5.9 & 6.3 & 6.8 & 7 & 8 \\
\hline \multicolumn{9}{|l|}{ Non-Hispanic, single-race white ${ }^{4}$} \\
\hline January & 212 & 190 & 189 & 6.9 & 6.5 & 6.5 & -6 & 0 \\
\hline February & 187 & 175 & 199 & 7.2 & 6.9 & 7.3 & -4 & 6 \\
\hline March & 196 & 181 & 269 & 6.8 & 6.3 & 9.4 & -7 & †49 \\
\hline April & 225 & 186 & 429 & 8.1 & 6.6 & 15.6 & $\dagger-19$ & †136 \\
\hline May & 206 & 193 & 461 & 6.7 & 6.5 & 15.8 & -3 & $\dagger 143$ \\
\hline June & 232 & 239 & 355 & 7.6 & 7.9 & 12.6 & 4 & †59 \\
\hline July & 258 & 247 & 304 & 8.2 & 7.7 & 10.6 & -6 & †38 \\
\hline August & 226 & 225 & 301 & 7.0 & 7.2 & 10.8 & 3 & $\dagger 50$ \\
\hline September & 190 & 207 & 265 & 6.7 & 7.3 & 10.1 & 9 & †38 \\
\hline October & 183 & 217 & 252 & 6.1 & 7.1 & 9.2 & 16 & †30 \\
\hline November & 166 & 161 & 205 & 5.7 & 5.8 & 8.4 & 2 & $\dagger 45$ \\
\hline December & 217 & 230 & 201 & 7.2 & 7.7 & 9.0 & 7 & 17 \\
\hline
\end{tabular}

See footnotes at end of table. 
Table. Births to New York City residents that occurred outside of New York City, by month and race and Hispanic origin of mother: Final 2018 and 2019 and provisional 2020 data-Con.

\begin{tabular}{|c|c|c|c|c|c|c|c|c|}
\hline \multirow[b]{2}{*}{ Race and Hispanic origin and month } & \multicolumn{3}{|c|}{ Number } & \multicolumn{3}{|c|}{ Percent } & \multicolumn{2}{|c|}{ Percent change } \\
\hline & $2018^{1}$ & $2019^{1}$ & $2020^{2}$ & $2018^{1}$ & $2019^{1}$ & $2020^{2}$ & 2018-2019 & 2019-2020 \\
\hline \multicolumn{9}{|l|}{ Non-Hispanic, single-race black ${ }^{4}$} \\
\hline January & 122 & 110 & 87 & 6.7 & 6.2 & 5.2 & -7 & -16 \\
\hline February & 67 & 97 & 106 & 4.1 & 6.2 & 7.0 & $\dagger 51$ & 13 \\
\hline March & 99 & 98 & 125 & 5.6 & 6.2 & 7.8 & 11 & 26 \\
\hline April & 123 & 113 & 127 & 7.7 & 7.1 & 8.3 & -8 & 17 \\
\hline May & 98 & 85 & 103 & 5.6 & 5.2 & 7.0 & -7 & †35 \\
\hline June & 111 & 107 & 100 & 6.5 & 6.8 & 6.6 & 5 & -3 \\
\hline July & 115 & 118 & 120 & 6.6 & 6.6 & 7.6 & 0 & 15 \\
\hline August & 108 & 117 & 117 & 5.8 & 6.6 & 7.7 & 14 & 17 \\
\hline September & 126 & 112 & 110 & 6.9 & 6.7 & 7.1 & -3 & 6 \\
\hline October & 110 & 102 & 112 & 6.0 & 6.0 & 7.6 & 0 & 27 \\
\hline November & 98 & 92 & 117 & 5.6 & 5.6 & 8.7 & 0 & $\dagger 55$ \\
\hline December & 92 & 127 & 84 & 5.3 & 7.5 & 6.0 & $\dagger 42$ & -20 \\
\hline \multicolumn{9}{|l|}{ Hispanic ${ }^{5}$} \\
\hline January & 151 & 116 & 127 & 5.5 & 4.6 & 5.1 & -16 & 11 \\
\hline February & 107 & 136 & 118 & 4.5 & 6.0 & 5.2 & $\dagger 33$ & -13 \\
\hline March & 138 & 125 & 136 & 5.4 & 5.2 & 5.7 & -4 & 10 \\
\hline April & 125 & 121 & 153 & 4.9 & 5.2 & 6.5 & 6 & $\dagger 25$ \\
\hline May & 169 & 155 & 158 & 6.3 & 6.3 & 6.7 & 0 & 6 \\
\hline June & 151 & 158 & 134 & 5.7 & 6.6 & 5.7 & 16 & -14 \\
\hline July & 141 & 148 & 142 & 5.2 & 5.6 & 5.6 & 8 & 0 \\
\hline August & 158 & 139 & 161 & 5.6 & 5.1 & 6.5 & -9 & $\dagger 27$ \\
\hline September & 150 & 153 & 146 & 5.7 & 5.7 & 6.0 & 0 & 5 \\
\hline October & 116 & 125 & 148 & 4.3 & 5.0 & 6.2 & 16 & 24 \\
\hline November & 159 & 135 & 123 & 6.2 & 5.4 & 5.7 & -13 & 6 \\
\hline December & 136 & 125 & 108 & 5.3 & 4.8 & 5.3 & -9 & 10 \\
\hline
\end{tabular}

†Significant change $(p<0.05)$

${ }^{1}$ Final data.

${ }^{2}$ Provisional data; based on $99.87 \%$ of births.

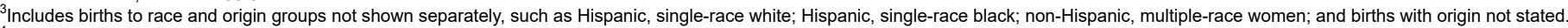

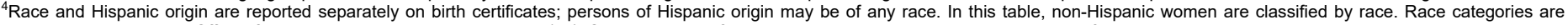
consistent with the 1997 Office of Management and Budget standards (10). Single-race is defined as only one race reported on the birth certificate.

${ }^{5}$ Includes all persons of Hispanic origin of any race.

SOURCE: National Center for Health Statistics, National Vital Statistics System, Natality.

- The percentage of non-Hispanic white NYC residents giving birth outside of the City in January and February was not significantly different for 2020 compared with 2019. In March, out-of-city births increased by $49 \%$, from $6.3 \%$ to $9.4 \%$. Out-of-city births increased again in April by $136 \%$ (6.6\% to $15.6 \%$ ) and in May by $143 \%$ (6.5\% to $15.8 \%)$. Out-of-city births continued to rise from June through November, with increases ranging from $30 \%$ to $59 \%$ (Table). The change in the percentage of out-of-city births for December was not significant. Figure 2 shows changes by race and Hispanic origin for April and May, the two months with the largest increases.

- The monthly percentage of nonHispanic black NYC residents giving birth outside of the City was generally unchanged for all but two months for 2020 compared with 2019. Levels rose in May by 35\% (from 5.2\% to $7.0 \%$ ) and in November by $55 \%$ (from $5.6 \%$ to $8.7 \%$ ) (Table and Figure 2).

- The monthly percentage of Hispanic NYC residents giving birth outside of the City was also generally unchanged for all but two months for 2020 compared with 2019. Levels increased in April by $25 \%$ (from $5.2 \%$ to $6.5 \%$ ) and in August by $27 \%$ (from $5.1 \%$ to $6.5 \%$ ) (Table and Figure 2).

\section{Summary}

From 2019 to 2020, the percentage of NYC residents giving birth outside of the City increased overall for all months from March through November, peaking in April and May. The timing of the increases in these out-of-city births corresponds with the height of the early pandemic in NYC (2). The overall rise in out-of-city births was largely the result of increases among non-Hispanic white women, for whom the percentage of outof-city births more than doubled in April and May 2020 and remained at least 30\% higher than the previous year through November. In contrast, out-of-city births increased in only two months among non-Hispanic black (May and November) and Hispanic (April and August) women. For 2018 and 2019, before the pandemic, the percentage of out-of-city births was essentially unchanged for most months for all NYC residents and for residents of each of the three largest race and Hispanic-origin groups. 
Figure 1. Births to all New York City residents that occurred outside of New York City: January-December 2018 to 2019 , and 2019 to 2020

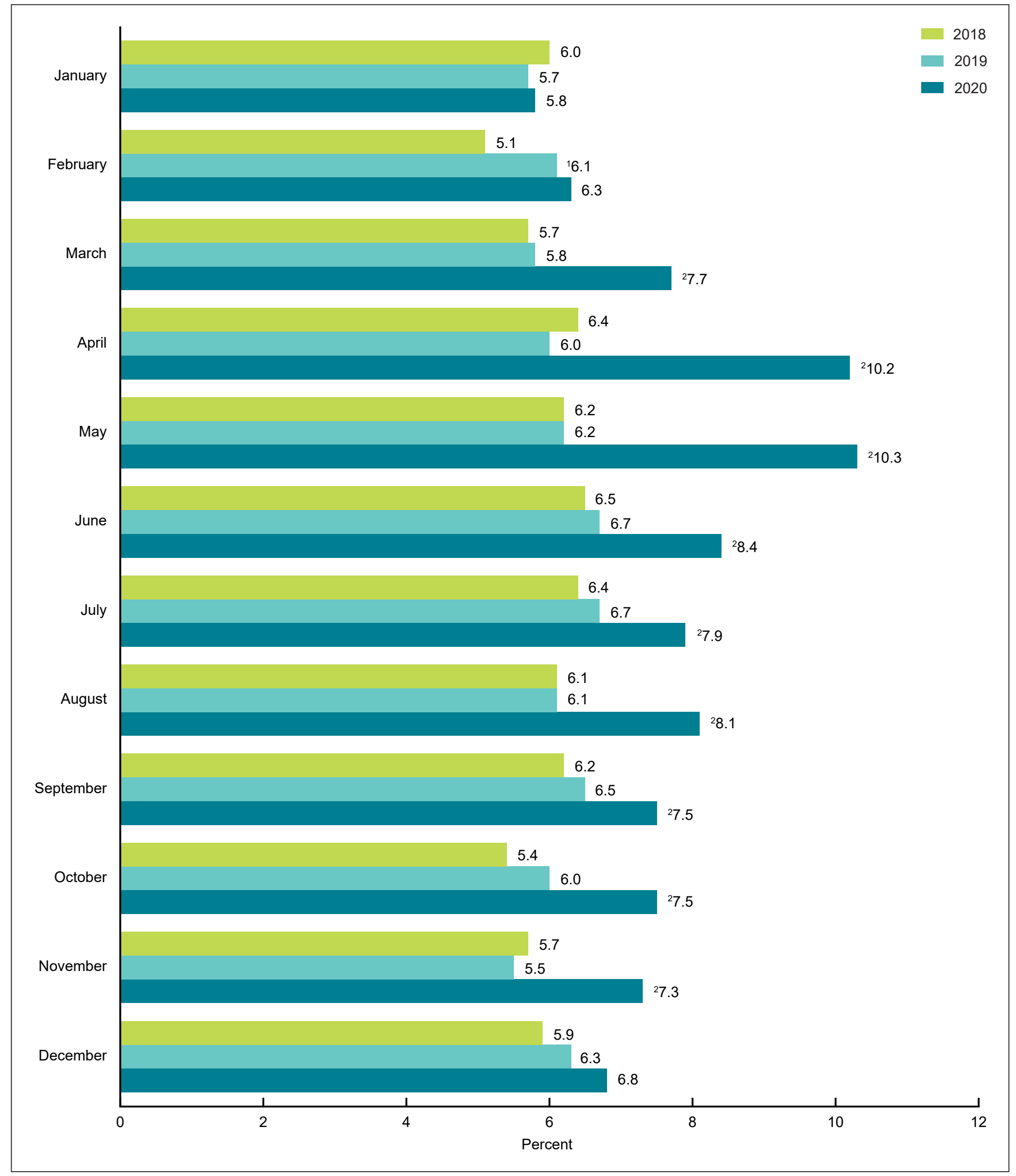

'Significant increase from $2018(p<0.05)$

${ }^{2}$ Significant increase from $2019(p<0.05)$

SOURCE: National Center for Health Statistics, National Vital Statistics System, Natality. 
Figure 2. Births to New York City residents that occurred outside of New York City, by race and Hispanic origin: April and May of 2019 and 2020

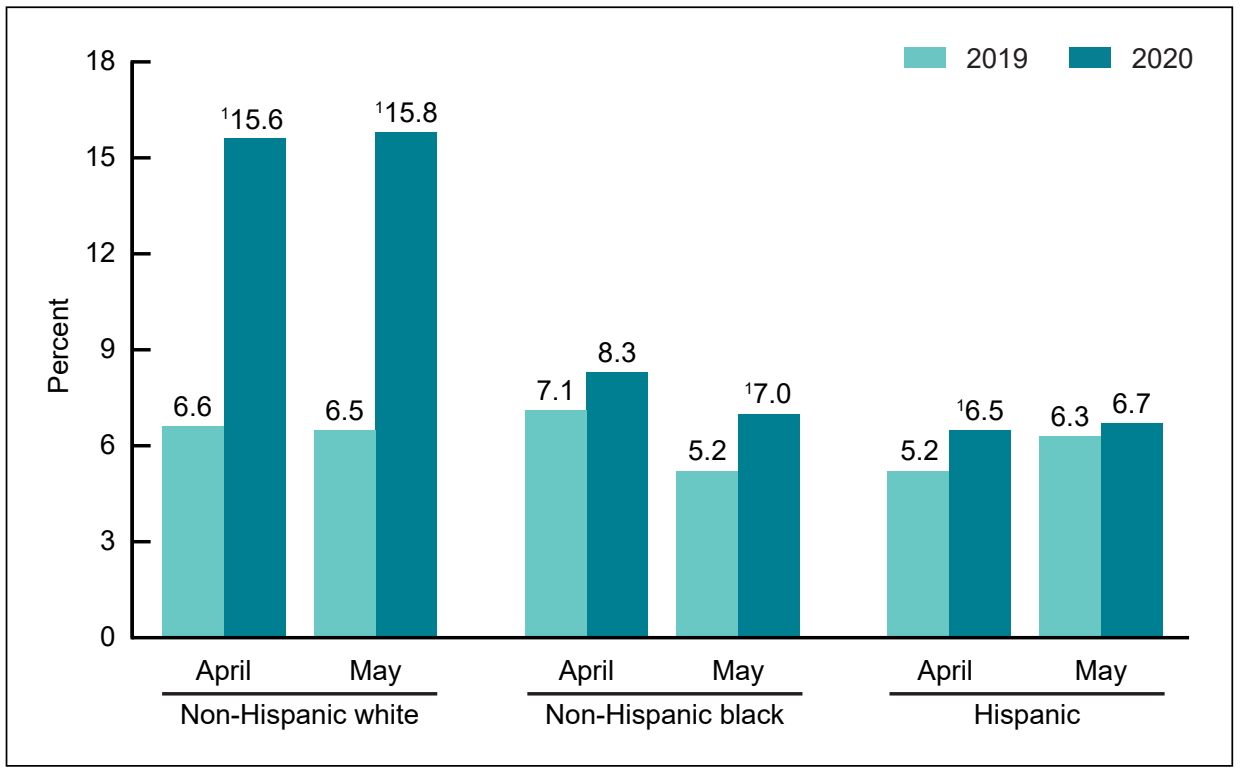

${ }^{1}$ Significant increase from $2019(p<0.05)$.

SOURCE: National Center for Health Statistics, National Vital Statistics System, Natality.

\section{References}

1. Thompson CN, Baumgartner J, Pichardo C, Toro B, Li L, Arciuolo R, et al. COVID-19 outbreak-New York City, February 29-June 1, 2020. MMWR Morb Mortal Wkly Rep 69(46):1725-29. 2020.

2. New York City Department of Health. COVID-19: Data-Cases, hospitalizations and deaths. Available from: https://www1.nyc.gov/site/ doh/covid/covid-19-data-trends.page.

3. Quealy K. The richest neighborhoods emptied out most as coronavirus hit New York City. The New York Times. May 15, 2020. Available from: https://www.nytimes.com/ interactive/2020/05/15/upshot/wholeft-new-york-coronavirus.html.

4. Caron C, Van Syckle K. Some pregnant women who can afford to are fleeing New York City. The New York Times. April 1, 2020. Available from: https://www.nytimes. com/2020/04/01/parenting/pregnantwomen-nyc-coronavirus.html.

5. Kusisto L, West MG. New York hospital systems ban partners from delivery room. The Wall
Street Journal. March 24, 2020. Available from: https:/www.wsj. com/articles/new-york-hospitalsystem-bans-partners-from-deliveryroom-11585004655.

6. New York State Department of Health. Health advisory: COVID-19 guidance for hospital operators regarding visitation updated guidance regarding obstetrical and pediatric settings. 2020. Available from: https://coronavirus. health.ny.gov/system/files/ documents/2020/03/doh_covid19 obpedsvisitation_032720.pdf.

7. Hamilton BE, Martin JA, Osterman MJK, Rossen LM. Births:

Provisional data for 2018. Vital Statistics Rapid Release; no 7. Hyattsville, MD: National Center for Health Statistics. 2019. Available from: https://www.cdc.gov/nchs/ data/vsrr/vsrr-007-508.pdf.

8. National Center for Health Statistics. User guide to the 2018 natality public use file. Available from: ftp:// ftp.cdc.gov/pub/Health_Statistics/ NCHS/Dataset_Documentation/ DVS/natality/UserGuide2018-508. pdf.
9. National Center for Health Statistics. Quarterly Provisional EstimatesTechnical Notes - Natality, Quarter 4, 2020. Available from: https:// www.cdc.gov/nchs/nvss/vsrr/natalitytechnical-notes.htm.

10. National Center for Health Statistics. Mother's worksheet for child's birth certificate. 2016. Available from: https://www.cdc.gov/nchs/data/dvs/ moms-worksheet-2016-508.pdf.

11. Office of Management and Budget. Revisions to the standards for the classification of federal data on race and ethnicity. Fed Regist 62(210):58782-90. 1997.

12. Hamilton BE, Martin JA, Osterman MJK, Driscoll AK, Rossen LM. Births: Provisional data for 2016. Vital Statistics Rapid Release; no 2. Hyattsville, MD: National Center for Health Statistics. 2017. Available from: https://www.cdc.gov/nchs/data/ vsrr/report002.pdf.

\section{Suggested citation}

Gregory ECW, Osterman MJK, Valenzuela CP. Changes in births to New York City residents occurring outside New York City, by race and Hispanic origin of the mother: 2018-2019 and 2019-2020. Vital Statistics Rapid Release; no 13. Hyattsville, MD: National Center for Health Statistics. 2021. DOI: https://doi.org/10.15620/cdc:104773.

\section{Copyright information}

All material appearing in this report is in the public domain and may be reproduced or copied without permission; citation as to source, however, is appreciated.

\section{National Center for Health Statistics}

Brian C. Moyer, Ph.D., Director

Amy M. Branum, Ph.D., Acting Associate Director for Science

\section{Division of Vital Statistics}

Steven Schwartz, Ph.D., Director

Isabelle Horon, Dr.P.H., Acting Associate Director for Science 